\title{
UPAYA MENINGKATKAN KERJASAMA SISWA PADA MATA PELAJARAN IPA MELALUI MODEL PEMBELAJARAN DUA TINGGAL DUA TAMU DI KELAS II SD NEGERI 182/1 HUTAN LINDUNG
}

\author{
SITI AISYAH NASUTION \\ SD Negeri 182/I Hutan Lindung, Muara Bulian,Batanghari,Jambi \\ e-mail: sitiaisyahnst0119@gmail.com
}

\begin{abstract}
ABSTRAK
Penelitian ini bertujuan untuk meningkatkan kerjasama siswa melalui model dua tinggal dua tamu pada siswa kelas II SD Negeri 182/1 Hutan Lindung,yang berlatar belakang masih banyak siswa kelas II SD Negeri 182/1 Hutan Lindung belum mampu melakukan kerjasama yang baik. . Dalam pembelajaran siswa cenderung belajar secara mandiri tanpa melakukan diskusi ataupun melakukan tanya jawab bersama dengan siswa lain.Khususnya Pelajaran IPA yang semestinya sangat memerlukan kerja sama dalam belajar untuk mencapai tujuan semaksimal mungkin.Hasil penelitian ini menunjukkan penerapan model dua tinggal dua tamu dapat meningkatkan kerjasama siswa kelas II SD Negeri 182/1 Hutan Lindung. Berdasarkan lembar observasi kerjasama siswa menunjukkan adanya peningkatan, terbukti dari siklus I pertemuan I terdapat 9 orang siswa dan pada pertemuan II terdapat 12 orang siswa yang mampu melakukan kerjasama pada siklus I. Kemudian pada siklus II meningkat pada pertemuan I terdapat 13 orang siswa dan pada pertemuan II terdapat 16 orang siswa yang mampu melakukan kerjasama pada siklus II. Tingkat keberhasilan mencapai 88.89 \% dengan kwalifikasi Sangat Baik (SB).Dalam hal ini dapat disimpulkan bahwa penerapan model dua tinggal dua tamu dapat meningkatkan kerjasama siswa pada mata pelajaran IPA di kelas II SD Negeri 182/1 Hutan Lindung.
\end{abstract}

Kata Kunci: Kerjasama, Model Dua Tinggal Dua Tamu.

\section{PENDAHULUAN}

Dalam proses pembelajaran guru harus mampu merancang pembelajaran yang menyenangkan, selain itu guru harus mampu meningkatan kerjasama siswa dalam proses pembelajaran yang telah berlangsung. Dalam proses pembelajaran yang telah berlangsung siswa harus mampu mandiri, percaya diri, tanggung jawab, begitu juga saling bekerjasama dalam sebuah kegiatan individu maupun sebuah kelompok untuk memecahkan masalah yang diberikan oleh guru dengan baik. Menurut Aunurahman dalam Rekysika (2015:15) "kerjasama merupakan fenomena yang pasti terjadi dalam berbagai kesempatan, dalam lapisan masyarakat dan berbagai bentuk kegiatan". Dengan bekerjasama manusia dapat lebih ringan dalam menyelesaikan permasalahan yang sedang diselesaikan.

Kerjasama yang dilaksanakan selama proses pembelajaran berlangsung dilakukan secara berkelompok. Menurut Roestiyah (2012:15) "penggunaan kerja kelompok untuk mengajar mempunyai tujuan agar siswa mampu bekerjasama dengan teman yang lain dalam mencapai tujuan bersama". Dimana dalam sebuah kelompok tersebut seluruh anggota kelompok harus saling membantu satu sama lain ataupun saling bekerjasama untuk memecahkan suatu permasalahan yang diberikan oleh guru. Dengan adanya pembelajaran secara berkelompok dapat memudahkan guru dalam menilai apakah setiap masing-masing siswa mampu bekerjasama dengan baik atau tidak.

Proses pembelajaran yang terjadi pada saat analisis proses pembelajaran yang dilakukan dari kegiatan pendahuluan, inti dan penutup masih banyak ditemukan bahwa kerjasama baik itu antara individu maupun kelompok masih sangat kurang. Selain itu, kerjasama yang dilakukan oleh siswa belum terlihat sehingga masih banyak siswa yang belajar secara mandiri. Seharusnya kerjasama antar siswa sangat baik ditumbuhkan sejak awal agar siswa mampu berbagi dan saling berdiskusi untuk menyelesaikan permasalahan baik itu di dalam maupun di luar pembelajaran..Prihal yang dirasakan oleh peneliti yang biasanya mengajar dikelas atas berbeda sekali ketika mengajar di kelas bawah. 
Ketika proses pembelajaran mata pelajaran IPA, peneliti merasa siswa lebih mementingkan diri sendiri,atau sebagian siswa tidak bersedia bekerjasama dengan temannya walaupun tidak bisa mengerjakan tugas, atau menyelesaikan permasalahan pembelajaran. Peneliti merasakan proses pembelajaran masih banyak berlangsung hanya satu arah.Saat dilemparkan pertanyaan kepada siswa, cendrung siswa menjawab serempak, sehingga sebagian siswa hanya menirukan ucapan temannnya.Pada proses pembelajaran IPA semestinya semua siswa merasakan dan bisa mengaktualisasikan diri secara bebas.Akibat dari pembelajaran yang demikian, hasil belajar siswa juga sangat rendah. Dilihat dari hasil ulangan harian ketuntasan belajar IPA yamg mencapai KKM hanya $49 \%$.

Pada tahun pelajaran kali ini peneliti berkebetulan ditugaskan di kelas bawah atau rendah yaitu kelas dua, merasa perlu menumbuhkan kerjasama yang baik. Menurut Rusman (2014:210) "tujuan penting dari pembelajaran kelompok adalah untuk mengajarkan kepada siswa keterampilan kerjasama dan kolaborasi”.

Kerjasama merupakan fenomena yang pasti terjadi dalam berbagai kesempatan, dalam lapisan masyarakat dan berbagai bentuk kegiatan. ( Aunurahman dalam Rekysika, 2015:15) Dengan bekerjasama manusia dapat lebih ringan dalam menyelesaikan permasalahan yang sedang diselesaikan.

Kerjasama yang dilaksanakan selama proses pembelajaran berlangsung dilakukan secara berkelompok. Menurut Roestiyah (2012:15) "penggunaan kerja kelompok untuk mengajar mempunyai tujuan agar siswa mampu bekerjasama dengan teman yang lain dalam mencapai tujuan bersama"..

Salah satu upaya agar proses pembelajaran yang dilaksanakan oleh guru menyenangkan dan siswa mampu melakukan kerjasama yang tinggi dalam pembelajaran yaitu dengan menerapkan model dua tinggal dua tamu (Two Stay Two Stray). Menurut Lie dalam Shoimin (2014:222) "model dua tinggal dua tamu merupakan model yang memberikan kesempatan kelompok untuk membagikan hasil dan informasi dengan kelompok lain".

Penelitian relevan yang dilakukan oleh Ranti Kumalasari yang dilakukan pada tahun 2011 dari Universitas Negeri Yogyakarta dengan judul penelitian "Upaya Mengingkatkan Prestasi Belajar Matematika Siswa Kelas III SD Negeri Klagen Dengan Menggunakan Model Pembelajaraan Kooperatif Tipe Two Stay Two Stray (TSTS)". Hasil penelitian menunjukkan adanya peningkatan, hal ini terlihat pada kondisi awal siswa $(38,10 \%)$ mengalami peningkatan pada siklus I $(71,43 \%)$ dan mengalami peningkatan yang signifikan pada siklus II $(80,95 \%)$.

Selanjutnya penelitian relevan yang dilakukan oleh Filumena Ajeng Nasiti pada tahun 2014 dari Universitas Sanata Dharma Yogyakarta.Dengan Judul penelitian "Peningkatan Kerjasama dan Prestasi Belajar IPS dengan Pembelajaran Kooperatif STAD pada Siswa Kelas III SD Kaanisius Kintelen I Yogyakarta. Hasil penelitian ini menunjukkan terjadinya peningkatan kerjasama dan prestasi belajar siswa. Tedapat peningkatan kerjasama pada kondisi awal rata-rata kerjasama siswa sebesar 55,39\% kemudian mengalami peningkatan pada sikluss I 68,82\% dan pada siklus II mengalami peningkatan 91,13\%.

Model dua tinggal dua tamu merupakan nama lain dari Two Stay Two Stray model pembelajaran tersebut termasuk dalam model kooperatif dimana model ini memberikan kesempatan kepada siswa untuk dapat bekerjasama dengan anggota kelompoknya. menurut Huda (2014:207) "model dua tinggal dua tamu dikembangkan oleh Spencer Kagan (1990) bahwa model ini dapat digunakan dalam semua mata pelajaran dan semua tingkatan usia peserta didik.

Menurut Huda (2014:207) "model pembelajaran dua tinggal dua tamu merupakan sistem pembelajaran kelompok dengan tujuan agar siswa dapat saling bekerja sama, bertanggung jawab, saling membantu memecahkan masalah, dan saling mendorong satu sama lain untuk berprestasi".Menurut Hanafiah(2009:56) "model dua tinggal dua tamu memberikan kesempatan kepada kelompok untuk membagikan hasil belajar dan informasi dengan kelompok lain". Menurut Ngalimun (2014:170-171) mengatakan bahwa "model pembelajaran dua tinggal dua tamu adalah cara siswa berbagi pengetahuan dan pengalaman dengan kelompok lain". 
Menurut Kesuma (2010:25) "kerjasama adalah sebuah konteks penting dalam CTL. Kebermaknaan meningkat dengan kerjasama. Para siswa dengan belajar mandiri biasanya bekerjasama dalam kelompok kecil dan otonom atau mandiri". Menurut Johnson (dalam Kesuma, 2010:26) "dengan bekerjasama terbuka memungkinkan untuk menemukan kekuatan dan kelemahan diri, belajar menghargai orang lain, mendengarkan dengan pikiran terbuka, dan membangun kesempatan kelompok".

Menurut Hurlock dalam (Rekysika, 2015:14) "kerjasama merupakan kemampuan bekerja bersama menyelesaikan suatu tugas dengan orang lain. Dalam proses bekerjasama, anak dilatih untuk dapat menekankan kepribadian individual dan mengutamakan kepentingan kelompok".

Menurut W.J.S Poerwadarminta dalam Rekysika (2015:15) "mendefinisikan kerjasama sebagai perbuatan bantu -membantu atau perbuatan yang dilakukan bersama-sama". Menurut Hawadi dalam Rekysika (2015:15) (kerjasama adalah membagi kegiatan dalam tugas-tugas kecil pada anggota kelompok". Dengan kegiatan bekerjasama maka pekerjaan akan menjadi lebih ringan, cepat selesai dan menumbuhkan semangat gotong royong, tolong menolong pada masing-masing peserta didik.

Menurut Kesuma (2010:26) terdapat beberapa hal yang dapat menjadi panduan untuk keberhasilan kerjasama antara lain: Tetap fokus dalam kelompok, Bekerja secara kooperatif dengan para anggota kelompok lainnya,Mencapai keputusan kelompok untuk tiap masalah, Menjamin bahwa setiap kelompok memahami setiap solusi yang ada sebelum melangkah lebih lanjut, Mendengarkan orang lain dengan seksama dan mencoba memaanfaatkan ide-ide mereka, Berbagai keepimpinan dalam kelompok,Nemastikan setiap orang berpartisipasi dan tidak ada salah seseorang yang mendomonasi dalam kelompok, dan Bergiliran memcatat hasilhasil yang telah tercapai kelompok.

Menurut Rohani (2010:30) "pada setiap pengajaran, guru hendaknya berupaya menciptakan suasana sosial yang membangkitkan kerjasama diantara peserta didik dalam menerima pelajaran sehingga pembelajaran terlaksana efektif dan efisien".

Menurut Rusman dalam (Prastowo, 2013:68) "menyatakan bahwa model pembelajaran biasanya disusun berdasarkan berbagai prinsip atau teori sebagai pijakan dalam mengembangkan". Menurut Trianto (2014:23) "model pembelajaran adalah perencanaan atau suatu pola yang digunakan sebagai pedoman dalam merencanakan pembelajaran dikelas atau pembelajaran tutorial dan untuk menentukan perangkat-perangkat pembelajaran termasuk didalamnya buku, film, komputer, kurikulum dan lain-lain.

Model dua tinggal dua tamu merupakan nama lain dari Two Stay Two Stray model pembelajaran tersebut termasuk dalam model kooperatif dimana model ini memberikan kesempatan kepada siswa untuk dapat bekerjasama dengan anggota kelompoknya. menurut Huda (2014:207) "model dua tinggal dua tamu dikembangkan oleh Spencer Kagan (1990) bahwa model ini dapat digunakan dalam semua mata pelajaran dan semua tingkatan usia peserta didik.

Menurut Huda (2014:207) "model pembelajaran dua tinggal dua tamu merupakan sistem pembelajaran kelompok dengan tujuan agar siswa dapat saling bekerja sama, bertanggung jawab, saling membantu memecahkan masalah, dan saling mendorong satu sama lain untuk berprestasi".Menurut Hanafiah(2009:56) "model dua tinggal dua tamu memberikan kesempatan kepada kelompok untuk membagikan hasil belajar dan informasi dengan kelompok lain". Menurut Ngalimun (2014:170-171) mengatakan bahwa "model pembelajaran dua tinggal dua tamu adalah cara siswa berbagi pengetahuan dan pengalaman dengan kelompok lain".

Menurut Suprijono dalam (Sari, 2015: 22-23) langkah-langkah model dua tinggal dua tamu adalah sebagai berikut :

1. Guru menyampaikan materi pelajaran atau permasalaahn kepada siswa sesuai dengan kompetensi dasar yang akan dicapai. 
2. Guru membentuk beberapa kelompok. setiap kelompok terdiri dari 4-5 orang siswa secara heterogen dengan kemampuan (tinggi, sedang, dan rendah) maupun jenis kelamin.

3. Guru memberikan Lembar Kerja Siswa (LKS) atau tugas untuk dibahas dalam kelompok.

4. Siswa 2-3 orang dari tiap kelompok berkunjung kekelompok berkunjung ke kelompok lain untuk mencatat hasil pembahasan LKS atau tugas dari kelompok lain, dan sisa kelompok tetap dikelompoknya untuk memerima siswa yang bertamu ke kelompoknya.

5. Siswa yang bertamu kembali kekelompoknya masing-masing dan menyampaikan hasil kunjungannya kepada teman yang tetap berada dalam kelompok. hasil kunjungan dibahas bersama dan dicatat.

6. Hasil diskusi kelompok dikumpulkan dan salah satu kelompok mempresentasikan jawaban mereka, kelompok lainnya memberikan tanggapan.

7. Guru memberikan klarifikasi terhadap jawaban yang benar.

8. Guru membimbing siswa merangkum pelajaran

9. Guru memberikan penghargaan secara kelompok.

\section{METODE PENELITIAN}

Metode penelitian ini adalah penelitian tindakan kelas ( PTK ). Dalam penelitian ini yang menjadi subjek penelitian yaitu siswa SD Negeri 182/1 Hutan Lindung Kelas II yang berjumlah 18 orang yang terdiri dari 10 orang laki-laki dan 8 orang perempuan

Penelitian ini memiliki beberapa tahap, yaitu : perencanaan, pelaksanaan, observasi, dan refleksi.Penelitian ini akan dilakukan dalam beberapa siklus. Siklus akan dihentikan apabila siswa sudah mengalami peningkatan pada kerjasama siswa, atau dalam kata lain data sudah menunjukkan bahwa model dua tinggal dua tamu.Siklus direncanakan akan dilakukan sebanyak 2 siklus apabila data sudah memenuhi kriteria keberhasilan maka siklus akan dihentikan, dan apabila data yang diperoleh selama 2 siklus masih kurang maka siklus akan ditambah sampai data sudah memenuhi kriteria keberhasilan. Model penelitian yang dipakai pada penelitian ini adalah model Kemis dan Mc. Taggart (Aries dan Haryono, 2012:125).

Untuk menafsirkan dan menyimpulkan hasil penelitian ditentukan kriteria keberhasilan. Penelitian dinyatakan berhasil kerjasama kelompok belajar siswa mengalami peningkatan setelah diterapkan model dua tinggal dua tamu di kelas II SD Negeri 182/1 Hutan Lindung. Kriteria ketuntasan individu adalah pada skala 70 atau berkualifikasi "Baik" dengan point tertinggi 100 . Kriteria kualifikasi itu berlaku pada aspek pembelajaran, yang meliputi aktivitas siswa dalam proses pembelajaran. Penelitian ini dianggap berhasil apabila $70 \%$ dari jumlah seluruh siswa sudah mencapai target dari indikator yang sudah ditetapkan.

\section{HASIL PENELITIAN \\ Hasil Penelitian Dan Pembahasan Siklus I \\ Siklus I pertemuan I}

Berikut ini akan dijelaskan dalam bentuk gambar mengenai peningkatan yang dialami oleh siswa dalam masing-masing indikator dan keseluruhan siswa yang mampu mengalami peningkatan dalam melakukan kerjasama. Gambar tersebut sebagai berikut: 


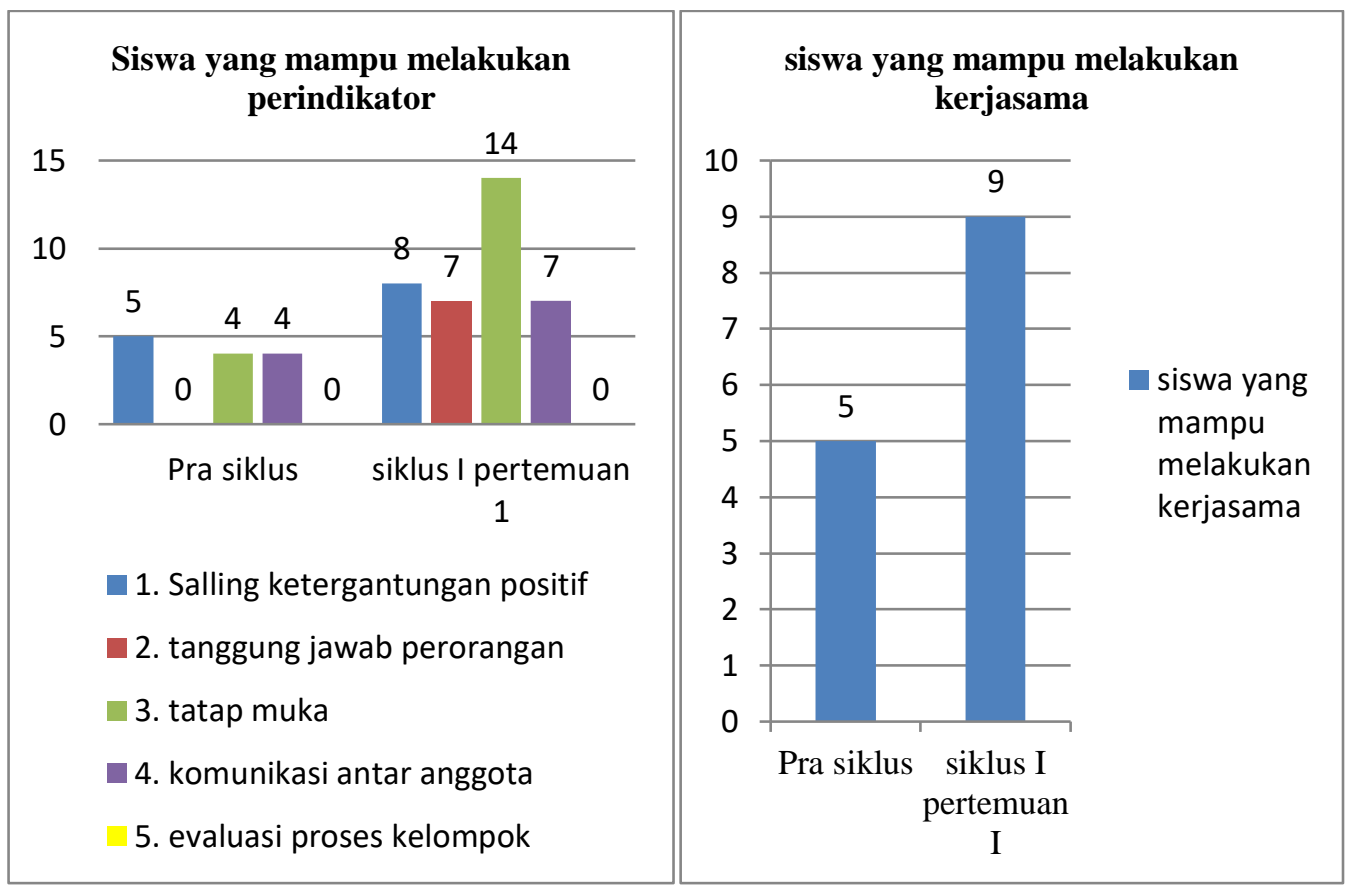

\section{Gambar 1. Grafik siswa yang mampu melakukan perindikator dan kerjasama siklus I pertemuan I}

Berdasarkan gambar di atas dapat disimpulkan bahwa pada pertemuan I ini menurut kriteria keberhasilan yang telah ditentukan belum mampu dikatakan berhasil dalam melakukan kerjasama.Untuk itu peneliti akan melakukan perbaikan-perbaikan pada pertemuan II agar terlaksana sesuai dengan kriteria keberhasilan yang telah ditentukan. Pada pertemuan ini terdapat beberapa siswa yang sudah mengalami perubahan, dimana pada saat prasilkus dalam mengikuti pembelajaran siswa hanya pasif, tidak memperhatikan guru saat mengajar, sering bermain, dan pada saat guru memberikan tugas siswa belum mampu menyelesaikan dengan baik, siswa belum mampu melakukan tanya jawab dan siswa lebih memilih untuk untuk tidak mengerjakan jika tidak memahaminya. Akan tetapi dengan diadakannya proses pembelajaran berkelompok siswa mampu melakukan kerjasama bersama dengan anggota kelompok yang telah dipilih oleh siswa itu sendiri melalui nomor undian yang diambil. Rata-rata perubahan yang dialami oleh siswa selama mengikuti pembelajaran berkelompok yaitu siswa mampu berdiskusi, bertanya jawab, bertanggung jawab terhadap tugas yang diterima, mengumpulkan informasi, menyampaikan pendapat yang diketahui dengan komunikasi yang baik dan jelas, mampu berinteraksi dan fokus dengan diskusi yang dilakukan bersama anggota kelompok, dan melakukan diskusi kembali

Pada pertemuan ini dalam proses pembelajaran yang dilakukan masih banyak siswa yang belum mengalami perubahan. Pada saat pembelajaran prasiklus terdapat salah satu siswa yang sudah mampu melakukan kerjasama akan tetapi pada saat dilakukan pembelajaran berkelompok siswa belum mampu melakukan. Penyebab siswa belum mampu mengalami peningkatan dimana siswa belum terbiasa dengan belajar berkelompok, siswa tidak nyaman dengan anggota kelompok yang didapat, kemudian siswa belum memiliki rasa percaya diri yang tinggi baik dalam berbicara maupun dalam melakukan diskusi, selain itu siswa belum mendapat kesempatan dari anggota kelompok untuk melakukan kerjasama dalam menyampaikan pendapat. Namun ada beberapa siswa yang memang pasif dalam mengikuti pembelajaran dimana siswa hanya diam, kadang-kadang dalam memperhatikan, dan main sendiri.

Berdasarkan hasil analisis lembar observasi siswa dan guru pada pertemuan I bahwa proses pembelajaran yang dilakukan belum dapat dikatakan berhasil, sehingga perlu dilakukan perubahan pada pertemuan I siklus I. Adapun kendala-kendala yang dihadapi pada pelaksanaan proses pembelajaran pada pertemuan I sebagai berikut:

a.) Kegiatan siswa dalam kelompok 
Dalam kegiatan yang berlangsung siswa masih ada yang sering ngobrol, bermaian baik dengan anggota kelompoknya maupun dengan kelompok lain, dalam diskusi kelompok masih ada beberapa orang siswa yang belum mampu mengikuti diskusi bersama anggota kelompok untuk memecahkan masalah, kemudian dalam bertanya jawab dan menyampaikan pendapat dengan mengkomunikasikan secara baik dan jelas siswa masih kurang.Faktor penyebab siswa belum terbiasa untuk belajar kelompok dan dalam berbicara baik dalam menyampaikan pendapat maupun melakukan tanya jawab siswa belum percaya diri. Selain itu dalam berdiskusi untuk memperkuat hasil jawaban siswa sebagian besar belum mampu melakukannya dan dalam diskusi yan dilakukan sebagian nsiswa ada yang belaum mampu memberikan kesempatan kepada siswa untuk saling berpartisipasi.

b.) Kegiatan guru

Dalam pelaksanaan kegiatan pembelajaran berdasarkan sintak dari model pembelajaran guru belum mampu dalam menyampaikan tujuan pembelajaran guru belum menguasai sehingga belum berurutan dan siswa belum mampu memahami apa yang sampaikan oleh guru, guru belum mampu mengaitkan materi pembelajaran yang sebelumnya,dalam menyampaikan pembalajaran guru masih menggunakan bahasa yang tinggi dan belum mampu mengola kelas, belum mampu mengatur waktu dalam pembagian waktu, guru belum mampu dalam membimbing siswa dalam menampilkan hasil diskusi dan membimbing siswa dalam menanggapi kelompok yang mempersentasikan hasil jawaban, kemudian dalam melakukan kesimpulan bersama dengan siswa guru . Guru sudah mampu menyimpulkan pembelajaran bersama dengan siswa akan tetapi guru belum membimbing siswa untuk dapat menemukan sendiri kesimpulan dalam proses pembelajaran yang telah dilakukan.

Untuk memperbaiki kekurangan-kekurangan yang ada pada pertemuan I, pada tindakan selanjutnya akan dilakukan perbaikan-perbaikan. Dimana perbaikan yang perlu dilakukan pada kegiatan guru yaitu guru tetap mempertahankan hal-hal yang baik yang telah terlaksana, guru lebih terampil dalam menyampaikan tujuan pembelajaran sehingga mudah dipahami oleh siswa, mengaitkan terlebih dahulu materi sebelumnya dengan materi yang akan diajarkan, mampu mengatur waktu dan mengelola kelas selama pembentukan kelompok, mampu membimbing siswa dalam melakukan persentasi dan membimbing siswa dalam menanggapi kelompok yang persentasi. Kemudian dalam menyimpulkan guru membimbing siswa untuk dapat menemukan sendiri kesimpulan dalam proses pembelajaran yang telah dilakukan.

\section{Siklus I Pertemuan II}

Berikut akan digambarkan beberapa peningkatan yang dpat dilami oleh siswa selama mengikuti proses pembelajaran yang dilakukan. 


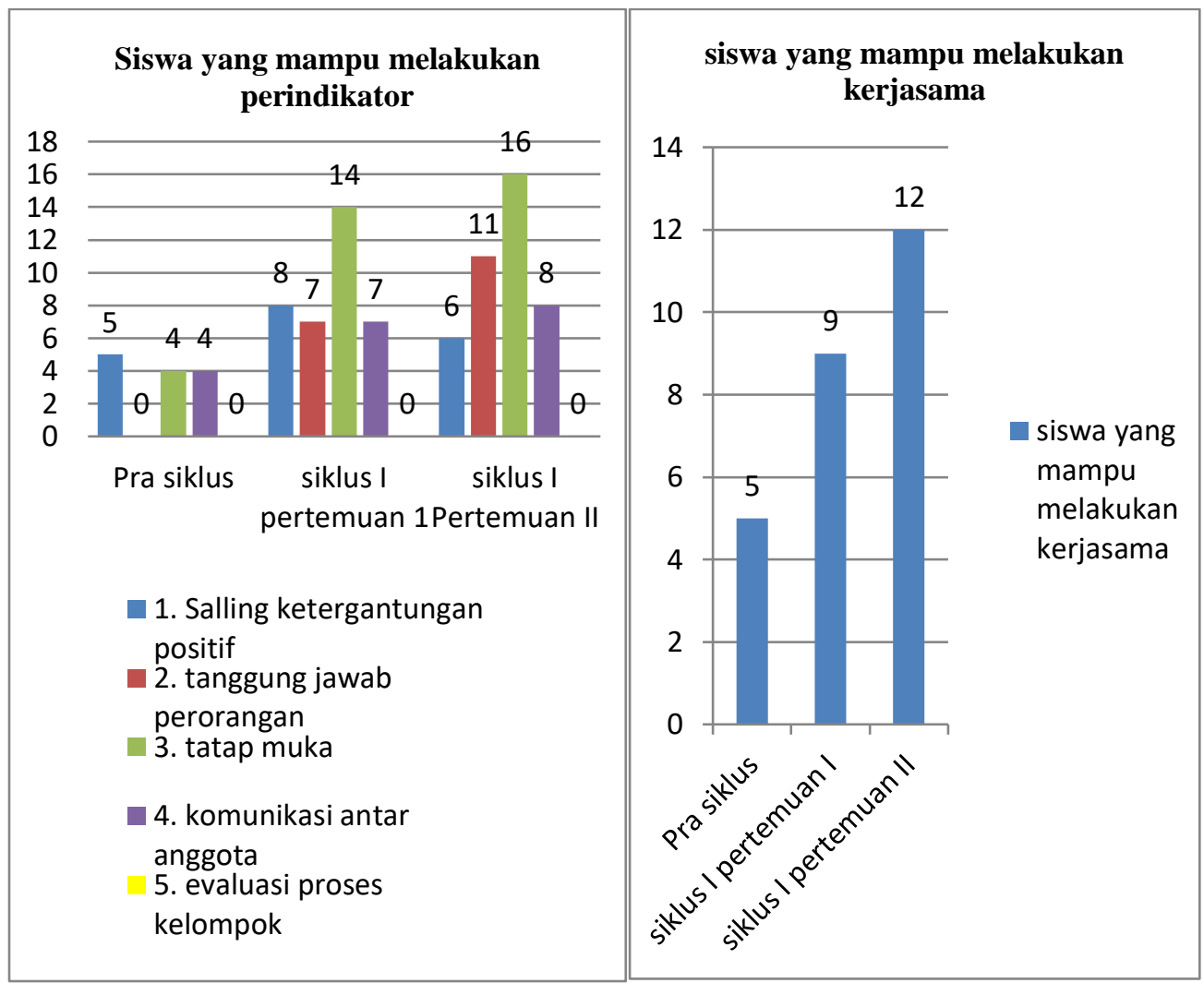

\section{Gambar 2. Grafik siswa yang melakukan perindikator dan kerjasama siklus I pertemuan 1 I}

Berdasarkan gambar diatas terdapat peningkatan yang dialami oleh siswa sebanyak 12 orang siswa,Perubahan yang dialami oleh masing-masing siswa sudah mampu dalam melakukan kerjasama mampu mengalami peningkatan berdasarkan indikator yang telah ditetapkan. Namun berdasarkan kriteria keberhasilan yang trlah ditentukan peningkatan yang dialami siswa masih belum berhasil, untuk itu peneliti akan melakukan perbaikan-perbaikan yang akan dilaksanakan pada silkus II.

Peningkatan yang dialami oleh siswa disebabkan karena siswa sudah senang dengan pembelajaran berkelompok, siswa sudah lebih aktif dari pembelajaran sebelumnya dimana pada pras iklus dan pertemuan I siswa masih ada yang suka bermain dan berbicara dengan siswa lain. Namun pada saat pembelajaran siswa sudah mampu mengikuti setiap diskusi yang dilakukan, setiap anggota sudah mampu saling berbagi baik dalam bergantian menulis dalam lembar kerja yang diberikan guru, bersama-sama dalam memecahkan masalah dengan melakukan tanya jawab terlebih dahulu untuk mengambil keputusan bersama.

Berdasarkan hasil analisis lembar observasi siswa dan guru pada pertemuan II bahwa proses pembelajaran yang dilakukan belum dapat dikatakan berhasil, sehingga perlu dilakukan perubahan pada pertemuan I siklus II. Adapun kendala-kendala yang dihadapi pada pelaksanaan proses pembelajaran pada pertemuan I sebagai berikut:

a.) Kegiatan siswa dalam kelompok

Dalam kegiatan yang dilakukan sudah mampu mengalami peubahan yang cukup baik terhadap siswa dimana dalam melakukan diskusi, tanya jawab, dan berkomunikasi dengan baik dan jelas masih banyak siswa yang belum mampu melakukannya, dimana siswa yang belum mampu melakukan disebabkan faktor dalam mengikuti kegiatan siswa belum percaya diri, belum myaman dengan kegiatan kelompok ataupun dengan anggota kelompok yang telah dibentuk. Dalam mengikuti proses pembelajaran siswa belum mampu saling berbagi sehingga siswa yang merasa belum mampu atau berkemampuan rendah belum mendapat kesempatan untuk menyampaikanbaik pendapat maupun saran yang diketahui oleh masing-masing individu. Kemudian sebagian siswa masih terbiasa dengan kegiatan sebelumnya dimana siswa 
mengerjakan sendiri dan mementingkan diri sendiri sehingga merasa pendapatnya yang paling benar.

b.) Kegiatan guru

Dalam pelaksanaan kegiatan pembelajaran berdasarkan sintak dari model pembelajaran guru sudah mampu menyampaikan tujuan pembelajaran yang mudah dipahami oleh siswa dan diingat oleh siswa, kemudian dalam mengaitkan materi pembelajaran sebelumnya guru sudah mampu melakukan, dalam menyampaikan materi yang diajaran sudah mudah untuk dipahami oleh siswa dengan menggunakan bahasa yang sederhana dan mengaitkan media yang digunakan, dalam pembagian kelompok guru sudah lebih efektif dengan menggunakan nomor undian akan tetapi dalam menuju kelompok masing-masing, namun masih membutuhkan waktu yang lama karena siswa masih ribut dan pengelolaan kelas belum tercapai dengan baik. kemudian dalam membimbing siswa dalam melakukan persentasi didepan kelas guru sudah mampu melakukan akan tetapi dalam membimbing siswa dalam menanggapi siswa masih rendah. Selanjutnya, dalam membimbing siswa untuk menyimpulkan pembalajaran guru sudah mampu melakukan, sedikit demi sedikit siswa sudah mampu menyimpulkan pembelajaran menggunakan bahasa yang dipahaminya.

Untuk memperbaiki kekurangan yang ada pada pertemuan II, pada tindakan selanjutnya akan dilakukan perbaikan-perbaikan. Dimana dalam melakukan perbaikan guru tetap mempertahankan hal-hal yang baik pada pertemuan II, guru harus lebih terampil dalam mengatur waktu pembagian kelompok, mampu mengelola kelas dengan baik, mampu membimbing siswa dalam menanggapi kelompok yang menampilkan hasil diskusi.

\section{Hasil Penelitian Dan Pembahasan Siklus II Siklus II Pertemuan I}

Berikut ini akan digambarkan peningkatan yang dialami siswa pada siklus II pertemuan I dimana siswa mengalami peningkatan dalam setiap indikator. Pada gambar di bawah ini, terdapat siswa sudah mampu mengalami peningkatan yang lebih baik dari pada pertemuan sebelumnya. Terdapat 13 orang siswa yang telah mampu melakukan kerjasama,namun belum mencapai kriteria keberhasilan yang telah ditentukan oleh peneliti. Selain itu terdapat penjelasan setiap indikator berapa siswa yang mampu mengalami peningkatan maupun penurunan.

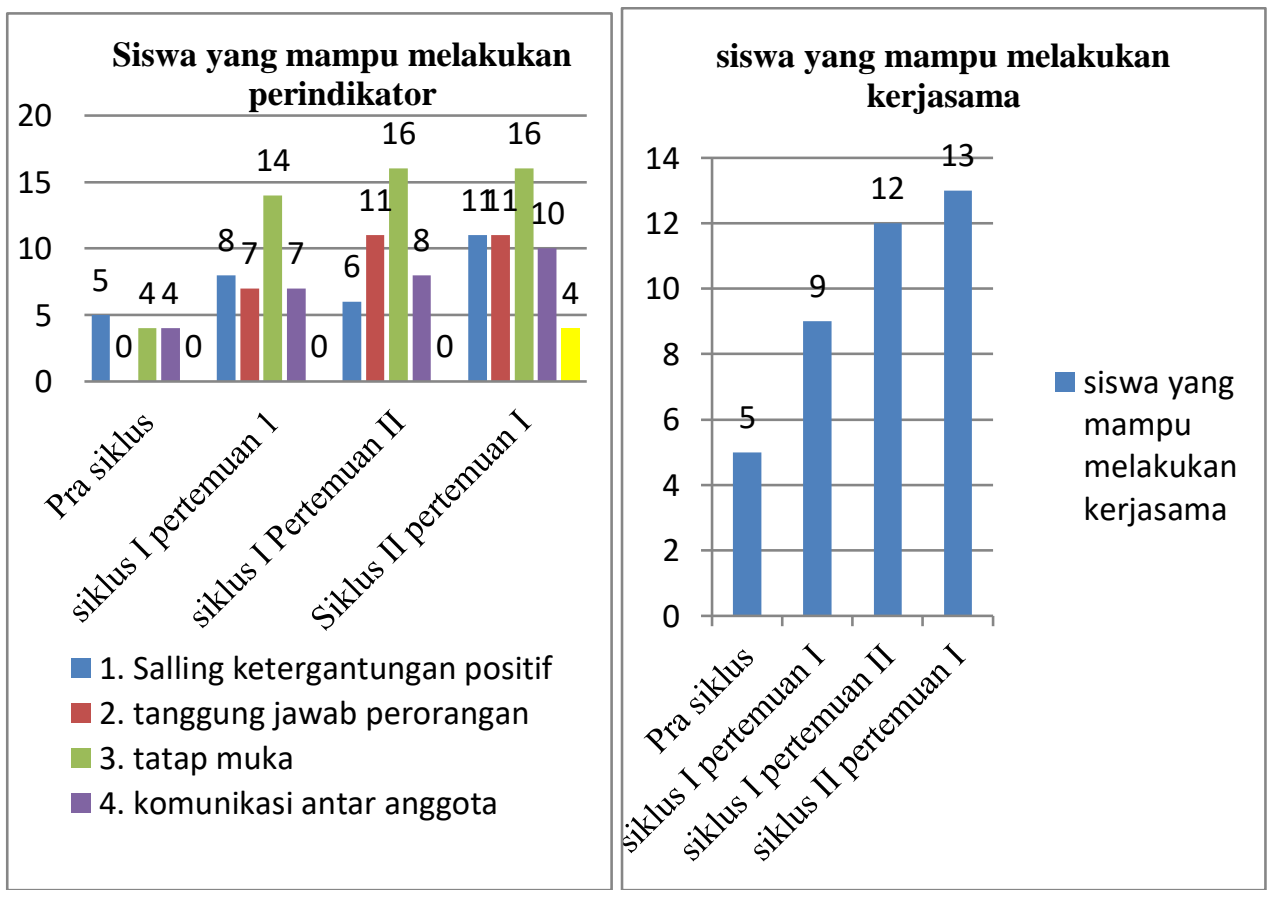

Gambar 3 grafik siswa yang mampu melakukan perindikator dan kerjasama siklus II pertemuan I 
Pada pertemuan ini rata-rata siswa sudah mampu melakukan peningkatan yang baik dimana setiap siswa sudah mampu dalam mengikuti diskusi dengan baik, mampu melakukan tanya jawab untuk mendapat kesepakatan bersama, sudah mampu terjadi interaksi antar anggota kelompok, fokus pada diskusi kelompok yang sedang berlangsung, mampu bertanggung jawab dengan tugas yang diterima, mampu menyampaikan pendapat dengan komunikasi yang baik dan jelas, dan mampu dalam melakukan diskusi kembali untuk memperkuat hasil jawaban dan mencocokkan hasil disksusi dengan hasil bertamu. Terlihat bahwa siswa sudah terbiasa dengan kegiatan yang dilakukan secara berkelompok, siswa lebih aktif dibandingakan pada pertemuan sebelumnya, siswa lebih banyak tertarik dengan setiap kegiatan yang dilakukan sehingga selalu ingin melakukan kerjasama bersama dengan anggota kelompok, dan mampu saling berbagi satu sama lain sehingga tidak ada lagi memilih-milih dalam kelompok selain itu siswa tidak hanya terpaku dengan satu siswa saja yang

Berdasarkan hasil analisis lembar observasi siswa dan guru pada siklus II pertemuan I bahwa proses pembelajaran yang dilakukan mengalami peningkatan dari pertemuan sebelumnya akan tetapi belum sesuai dengan kriteria keberhasilan, sehingga perlu dilakukan perubahan pada pertemuan I siklus II. Adapun kendala-kendala yang dihadapi pada pelaksanaan proses pembelajaran pada pertemuan I sebagai berikut:

a. Kegiatan siswa dalam kelompok

Dalam kegiatan pembelajaran yang dilakukan siswa sudah mengalami perubahan yang cukup baik dimana sebagian sisa sudah mampu bekerjasama dengan kelompok sesuai dengan indkator yang telah ditetapkan. Akan tetapi ada beberapa siswa yang belum mampu melakukan kerjasama bersama dengan anggota kelompoknya. Secara garis besar siswa yang belum mampu mengalami perubahan dalam bentuk melakukan tanya jawab, menyampaikan pendapat dengan komunikasi yang baik dan jelas, melakukan diskusi kembali untuk memperkuat hasil jawaban. faktor yang mempengaruhi dimana siswa belum memiliki rasa percaya diri yang tinggi dalam ikut berpartisipasi dalam kelompok.

b. Kegiatan guru

Dalam pelaksanaan kegiatan pembelajaran berdasarka sintak model dua tinggal dua tamu guru sudah mampu dalam menyampaikan tujuan pembelajaran, mengaitkan materi sebelumnya dengan materi yang akan diajarkan, mampu menyampaikan materi dengan baik, mengatur waktu dalam pebentukan kelompok,membimbing siswa dalam mengajukan pertanyaan mengenai yang tidak diketahui. Namun dalam mengelola kelas guru masih kurang memperhatikan segingga masih ada siswa yang bermain dan tidak mengikuti diskusi, kemudian dalam membimbing siswa menampilkan hasil diskusi guru sudah mampu akan tetapi dalam membimbing siswa untuk menanggapi kelompok yang tampil siswa belum mampu melakukannya.

Untuk memperbaiki kekurangan-kekurangan yang ada pada siklus II pertemuan I, pada tindakan selanjutnya akan dilakukan perbaikan-perbaikan. Dimana dalam melakukan perbaikan guru tetap mempertahankan hal-hal yang baik pada siklus II pertemuan I, guru harus lebih terampil mampu mengelola kelas dengan baik, mampu membimbing siswa dalam menanggapi kelompok yang menampilkan hasil diskusi.

\section{Siklus II Pertemuan II}

Pada pertemuan ini siswa mampu mengalami peningkatan dalam melakukan indikator ini. Terlihat bahwa pada pertemuan sebelumnya siswa belum mampu melakukan diskusi kembali untuk memperkuat hasil jawaban namun pada pertemuan ini terdapat 11 orang siswa yang mampu melakukan. Karena siswa mendorong dan membimbing siswa untuk dapat melakukan evaluasi bersama dengan anggota kelompok. 


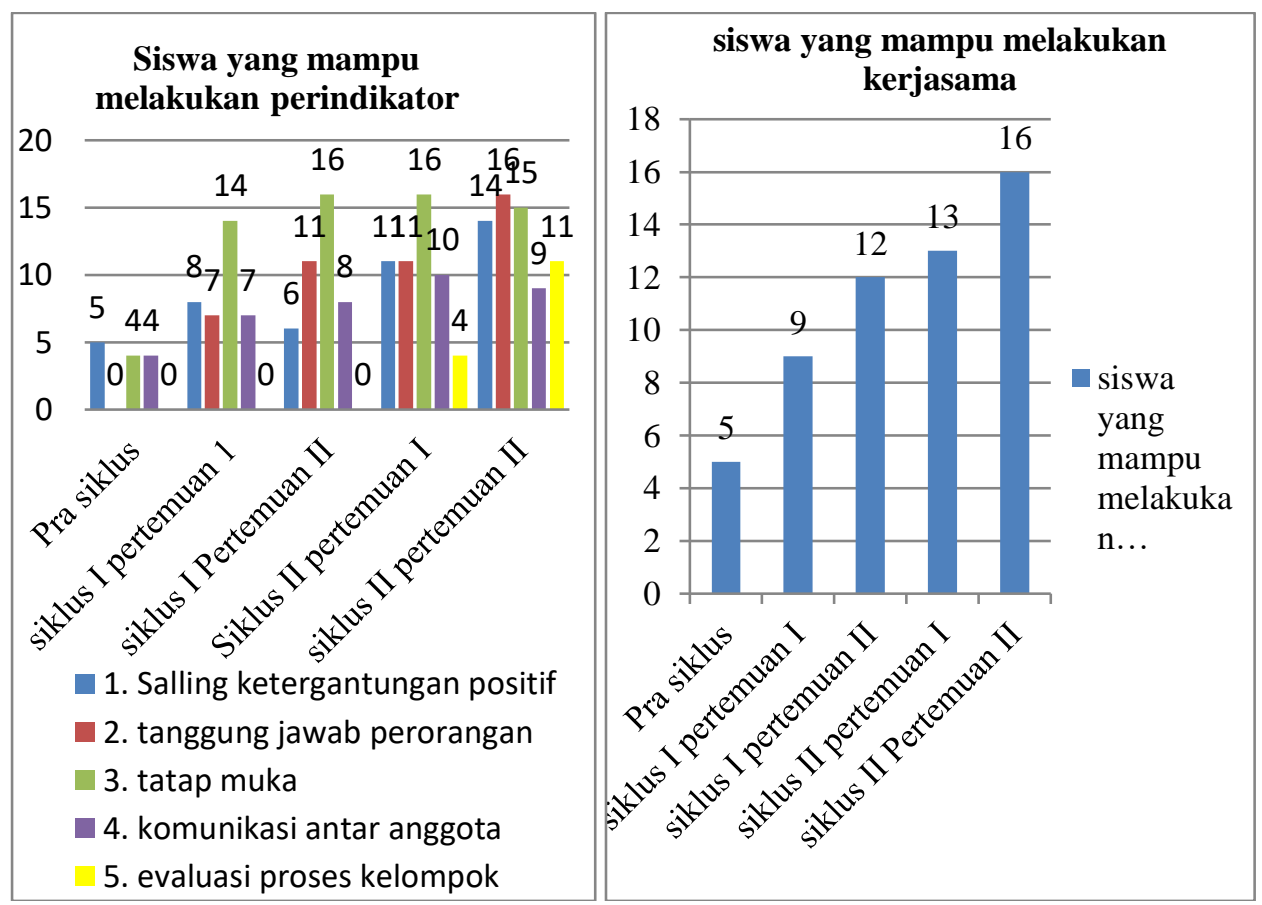

Gambar 4 grafik siswa yang mampu melakukan perindikator dan kerjasama siklus II pertemuan II

Pada gambar diatas, siswa yang sudah mengalami peningkatan yang baik dimana dari jumlah siswa 18 orang,sebanyak 16 orang siswa yang telah mampu melakukan kerjasama dalam kelompok yang dibentuk dengan menerapakan model dua tinggal dua tamu. Dalam pembelajaran yang dilakukan selama 4 kali pertemuan ini siswa sudah mampu mengalami peningkatan dari yang belum mampu melakukan sama sekali hingga mampu melakukan semuanya. Peningkatan itu dalam bentuk melakukan diskusi bersama untuk memecahkan masalah, melakukan tanya jawab, tanggung jawab terhadap tugas yang didapat baik menjadi tamu (mengumpulkan informasi) maupun tugas tinggal (menyampaikan informasi), mengumpulkan informasi, interaksi dengan anggota kelompok, fokus dalam memeprhatikan kerjasama yang sedang berlangsung, menyampaikan pendapat dengan komunikasi yang baik dan jelas, kemudian mampu melakukan diskusi bersama dalam memperkuat hasil jawaban ataupun diskusi dalam mencocokkan hasil jawaban dengan hasil bertamu. peningkatan ini dialami secara bertahap dimana tidak semua siswa langsung mampu melakukan semua indikator. Dibandingkan dengan pembelajaran yang dilakukan pada saat pra siklus, pada saat pembelajaran dengan menerapkan model ini pembelajaran yang dilakukan lebih bermakna. Dimana siswa mampu saling bekerjasama dan siswa mampu memahami bahwa kebersamaan dan interaksi antar siswa itu penting sehingga antara siswa satu dengan yang lain tidak merasa terasingkan, kemudian siswa juga mampu membantu siswa lain yang mengalami kekurangan dalam bentuk membimbingng siswa agar sama-sama mampu memahami setiap pembelajaran yang dilaksankan oleh guru.

Berdasarkan hasil observasi pada siklus II pertemuan II, kerjasama kelompok belajar siswa sudah meningkat dari pertemuan sebelumnya. Dari pengamatan yang telah dilakukan, dapat disimpulkan bahwa dengan menerapkan model dua tinggal dua tamu dapat meningkatkan kerjasama kelompok belajar IPA siswa di kelas II SD Negeri 182/1 Hutan Lindung, guru harus tetap membimbing siswa dan memahami setiap kebutuhan siswa serta menciptakan suasana interaktif dengan siswa. Berdasarkan pengamatan pada siklus II pertemuan II ini,maka tindakan akan dihentikan karena kerjasama kelompok belajar siswa telah mencapai target yang telah ditetapkan.Terdapat 16 siswa dari 18 siswa $(88,89 \%)$ yang dapat melakukan kerjasama dengan baik. Berdasarkan hasil observasi kerjasama siswa yang meningkat pada siklus I sampai siklus II, maka dapat disimpulkan bahwa penelitian ini berhasil pada silkus II. 


\section{KESIMPULAN}

Penelitian ini dilakukan pada siswa kelas II di SD Negeri 1821 Hutan Lindung sebanyak dua siklus dengan menerapkan model dua tinggal dua tamu pada proses pembelajaran. Selama penelitian siklus I dilakukan kerjasama siswa kelas II berada pada kategori cukup baik, selanjutnya, peneliti memperhatikan kekurangan pada tahap observasi guru dan siswa. Jika kekurangan-kekurangan pada hasil siklus I tidak optimal, maka akan diperbaiki pada siklus II. Setelah dilakukan perbaikan-perbaikan pada siklus II, terbukti bahwa model dua tinggal dua tamu dapat meningkatkan kerjasama pada mata pelajaran IPA di kelas II SD Negeri 182/1 Hutan Lindung.

Berdasarkan penelitian ini, dapat disimpulkan bahwa kerjasama siswa kelas II SD Negeri 182/1 Hutan Lindung terkait indikator pertama yaitu saling ketergantungan positif, kedua bertanggung jawab perorangan, ketiga tatap muka, keempat komunikasi antar anggota, dan kelima evaluasi proses kelompok. Hal ini dapat dilihat dari siswa yang telah mampu berdiskusi untuk memecahkan masalah, melakukan tanya jawab untuk mendapatkan kesepakatan bersama, siswa mampu berinteraksi dengan anggota kelompok, dengan fokus memperhatikan diskusi kelompok yang sedang berlangsung, menyampaikan pendapat dengan komunikasi yang baik dan jelas. Dan melakukan diskusi kembali dalam memperkuat hasil jawaban dan berdiskusi untuk mencocokkan hasil diskusi dan hasil bertamu.

Dari hasil penelitian tersebut, maka terbukti dengan menerapakan model dua tinggal dua tamu dapat meningkatkan kerjasama siswa pada mata pelajaran IPA di kelas II SD Negeri 182/1 Hutan Lindung. Tingkat keberhasilan mencapai 88,89 \% dengan kualifikasi Sangat Baik. Dengan kata lain model dua tinggal dua tamu dapat berhasil untuk mencapai tujuan dalam meningkatkan kerjasama. Keberhasilan model ini karena sesuai karakteristiknya yang dapat membangkitkan kerjasama dan keingintahuan siswa untuk belajar dan berinteraksi dengan siswa lain, menuntut siswa untuk berpikir secara mandiri terhadap masalah yang ditemukannya.

\section{DAFTAR PUSTAKA}

Aries, Erna Febru dan Ari Dwi Haryono. (2012). Penelitian Tindakan Kelas. Yogyakarta: Aditya Media Publishimg

Djamarah, S,B. (2010). Guru dan Anak Didik Dalam Interaksi Edukatif: Suatu Pendekatan Teoritis Psikologis. Jakarta: Rineka Cipta.

Hanafiah, Nanang \& Suhana, C. (2009). Konsep Strategi Pembelajaran. Bandung: PT Refika Aditama.

Hardini, Isriani, dkk. (2012). Strategi Pembelajaran Terpadu: Teori, Konsep, Implementasi. Yogyakarta: Familia (Group Relasi Inti Media).

Huda, Miftahul. (2014). Model- Mpdel Pengajaran: Isu-Isu Metodis Paradigmatis. Yogyakarta: Pustaka Pelajar.

Istarani. (2014). Model Pembelajaran Inovatif. Medan: Media Persada.

Kesuma, Dharma,dkk. (2010). Contextual Teaching And Learning. Yogyakarta: Rahayasa.

Nasiti, F. A. (2014). Peningkatan Kerjasama dan Prestasi Belajar IPS Dengan Peembelajaran Kooperatif STAD Pada Siswa Kelas III SD Kanisius Kintelan 1 Yogyakarta. Dalam ejurnal: Universitas Sanata Dharma.

Ngalimun. (2014). Strategi dan Model Pembelajaran. Yogyakarta: Aswaja Pressindo.

Ostroff, W, L. (2013). Memahami Cara Anak-Anak Belajar: Membawa Ilmu Perkembangan Anak didlam Kelas. Jakarta Barat: PT Indeks.

Prastowo, Andi. (2013). Pengembangan Bahan Ajar Tematik. Baturetno: Diva Press.

Rekysika, N, S. (2015). Upaya Meningkatkan Kemampuan Kerjasama Melalui Kegiatan Kerja Kelompok A TK Negeri Trukan Siwates Kali Guntur Temon Kulon Progo. dalam ejurnal: Universitas Negeri Yogyakarta.

Roestiyah N, K. (2012). Strategi Belajar Mengajar. Jakarta: Rineka Cipta.

Rohani, Ahmad. (2010). Pengelolaan Pengajaran: Sebuah Pengantar Menuju Guru Profesional. Jakarta: PT Rineka Cipta. 
Rusman. (2014). Model-Model Pembelajaran: Mengembangkan Profesionalisme Guru. Jakarta: PT Rajagrafindo Persada.

Samatowo, Usman. (2006). Bagaimana Membelajarkan IPA di Sekolah Dasar. Direktor Jendral Pendidikan Tinggi: Departemen Pendidikan Nasional.

Sari, I, M. (2015). Penerapan Model Pembelajarab Kooperatif Tipe Dua Tinggal Dua Tamu (two stay two stray) Untuk Meningkatkan Hasil Belajar IPA Kelas V SDN-3 Pahandut Palangkaraya. Dalam e-jurnal: Universitas Muhammadiyah Palangkaraya.

Shoimin, Aris. (2014). Modeel Pembelajaran Inovatif dalam Kurikulum 2013. Yogyakarta: AR-Ruzz Media.

Siburian, Jodian \&Asrial. (2010). Model Pembelajaran Sains. Jakarta: Gaung Persada (GP) Press.

Suyono, dkk. (2012). Belajar dan Pembelajaran. Bandung: PT Remaja Rosdakarya.

Trianto. (2012). Model Pembelajaran Terpadu: Konsep Strategi, dan Implementasinya dalam kurikulum Tingkat satuan Pendidikan (KTSP). Jakarta: Bumi Aksara.

Trianto, Ibnu, B, A. (2014). Mendesain Model Pembelajaran Inovatif, Progresif, dan Kontekstual: Konsep, Landasan, dan Implementasinya pada kurikulum 2013 (Kurikulum Tematik Integratif/ TKI). Jakarta: Prenadamedia Group.

Woolflk, Anita. (2009). Educational Psychology Active Learning Edition: Edisi kesepuluh Bagian Kedua. Yogyakarta: Pustaka Pelajar.

Yamin, Martinis, dkk. (2013). Srategi dan Metode dalam Model Pembelajaran. Jakarta: Referensi (Gp Press Group). 